Original Research

\title{
Potensi dan Strategi Pengembangan Objek Wisata Tahura Lapak Jaru Kuala Kurun Kabupaten Gunung Mas Provinsi Kalimantan Tengah
}

\author{
Herianto ${ }^{1,2,{ }^{*}}$ Abdul Mukti ${ }^{2}$, Renhart Jemi ${ }^{2,3}$ \\ ${ }^{1}$ Dinas Pertanian Kabupaten Gunung Mas \\ ${ }^{2}$ Program Studi Magister Pengelolaan Sumberdaya Alam dan Lingkungan Universitas Palangka Raya \\ 3 Jurusan Kehutanan Fakultas Pertanian Universitas Palangka Raya \\ * Korespondensi: Herianto (E-mail: anto84574@gmail.com)
}

\begin{abstract}
Conservation areas are known for their significant functions to protect the plant and animal biodiversity, as well as their ecosystems. Lapak Jaru Tahura, which is located in Gunung Mas Regency, Central Kalimantan, is one of the conservation areas with potential ecotourism attraction. The strategy for developing tourist objects and natural attractions in Tahura Lapak Jaru needs to be formulated to gain positive impact and to reach its sustainability. The purpose of this study was to dig ecotourism potential in Tahura Jaru Kuala Kurun and to formulate tourism development strategies in the Tahura Lapak Jaru in Kuala Kurun tourist area. This research was conducted through 2 (two) stages of analysis. First, identifying the tourism potential in the Tahura Jaru Kuala Kurun area with descriptive analysis. Second, formulating a tourism development strategy in the Tourism Area of the Lapak Jaru Kuala Kurun tourism area with a SWOT analysis. The results showed that the Lapak Jaru Tahura is a very potential site for further development to become a tourist attraction. The strategy of Tahura Lapak Jaru development is aggressive, namely, to use the strength they have to take advantage of current opportunities. These strategies, among others, are, first, to maintain its position as a tourism destination which fully supported by local government and the ease of gaining potential investor. Second, regional development planning needs to include the participation of local communities so that target consumers who tend to like nature tourism can be achieved.
\end{abstract}

\section{Keywords}

Potential, Strategy, Development, Tahura, SWOT

\section{PENDAhUluAN}

Sumberdaya alam dan budaya di dalam kawasankawasan konservasi merupakan potensi yang besar untuk dapat dimanfaatkan untuk pengembangan ekowisata (Sahureka et al., 2016). Kawasan konservasi mempunyai karakteristik yang spesifik dan khusus serta mempunyai manfaat utama dalam perlindungan biodiversitas tumbuhan dan satwa serta ekosistemnya (Mulyanie, 2016). Kesatuan ekosistem yang merupakan asosiasi antara biodiversitas yang ada memiliki potensi sebagai objek wisata yaitu ekowisata.

Pengembangan ekowisata harus menggunakan kaidah-kaidah keberlanjutan yang dapat menciptakan peluang peningkatan ekonomi bagi masyarakat lokal dan memberikan perlindungan kawasan konservasi dan lindung, membuka ruang untuk memberikan penghormatan hak atas sumberdaya alam, baik bersifat perorangan maupun kelompok demi terciptanya keuntungan dan kesetaraan kepentingan sosial, ekonomi dan lingkungan (Wulan et al., 2019). Ekowisata mengutamakan upaya konservasi sumberdaya alam, pengembangan ekonomi dan pemberdayaan masyarakat yang dilakukan secara baik, benar, bertanggung jawab serta berkelanjutan (Afriza et al., 2018).

Taman Hutan Raya (Tahura) Lapak Jaru merupakan satu-satunya Tahura yang terdapat di Kabupaten Gunung Mas, Provinsi Kalimantan Tengah yang ditetapkan berdasarkan Keputusan Menteri Lingkungan Hidup dan Kehutanan Republik Indonesia Nomor: SK.240/Menlhk/ Setjen/PKTL.2/3/2016 tanggal 24 Maret 2016 seluas \pm 4.119 ha. Kondisi kawasan Tahura Lapak Jaru saat ini masih sangat alami dengan keindahan alamnya yang masih terjaga. Flora dan fauna yang masih terjaga dengan kondisi alamnya yang alami memiliki potensi dijadikan sebagai objek wisata alam di Kabupaten Gunung Mas. PHKA (2003) menjelaskan bahwa keanekaragaman hayati, keunikan dan keaslian budaya 
tradisional, keindahan bentang alam, gejala alam serta peninggalan sejarah/budaya adalah anugerah Tuhan yang berpotensi sebagai objek dan daya tarik wisata alam (ODTWA).

Tahura Lapak Jaru dapat dikembangkan menjadi objek wisata yang potensial apabila ada sumber daya manusia yang memadai dan didukung para pihak terkait dan khususnya masyarakat setempat dalam implementasi penerapan fungsi-fungsi pengelolaan yang baik. Namun sampai pada tahap ini perencanaan pengelolaan hanya melibatkan instansi tertentu yaitu Dinas Lingkungan Hidup Kabupaten Gunung Mas dan belum melibatkan masyarakat dalam perencanaan pengelolaannya. Oleh karena itu perencanaan pengembangan Tahura Lapak Jaru memerlukan koordinasi yang baik antar intansi terkait yang berperan dan masyarakat lokal. Peluang kerjasama juga perlu ditingkatkan dalam upaya meningkatkan pengembangannya. Menurut Hidayat (2016), keterlibatan masyarakat setempat merupakan salah satu upaya untuk mencapai keberhasilan dalam pengembangan suatu wilayah. Latupapua et al. (2013) menyatakan bahwa keterlibatan masyarakat sangat diperlukan baik langsung maupun tidak langsung karena membantu dalam hal pengembangan suatu objek daya tarik ekowisata.

Tahura Lapak Jaru yang memiliki potensi ODTWA membutuhkan perencanaan yang dapat memberikan gambaran bagaimana pariwisata dan hal-hal yang berkaitan dengan wisata untuk pengelolaanya kedepan. Diperlukan adanya analisis tentang potensi dan strategi untuk pengembangan objek wisata Tahura Lapak Jaru di Kabupaten Gunung Mas. Pentingnya perencanaan dalam pengembangan pariwisata sebagai suatu industri tidak lain adalah agar perkembangan industri periwisata sesuai dengan apa yang telah dirumuskan dan berhasil mencapai sasaran yang dikendaki baik itu ditinjau dari segi ekonomi, sosial, budaya dan lingkungan hidup. Adanya perencanaan dapat menginformasikan bagaimana kondisi implementasinya secara lebih efisien dan sesuai dengan kondisi kawasan yang dikelola (Sulisyati et al., 2016).

\section{METODOLOGI}

Penelitian dilaksanakan di Kawasan Wisata Tahura Lapak Jaru Kuala Kurun Kabupaten Gunung Mas Provinsi Kalimantan Tengah. Penelitian dilakukan selama 4 bulan yaitu bulan Oktober 2019 sampai dengan bulan Januari 2020. Rancangan dalam penelitian ini adalah penelitian deskriptif dengan pendekatan kuantitatif. Penelitian ini dilaksanakan melalui dua tahap. Tahap pertama melakukan identifikasi faktor internal (strength dan weakness) dan eksternal (opportunity dan treath).

Teknik analisis yang digunakan dalam penelitian ini adalah deskriptif dan SWOT (Strengths, Weakness, Opportunities, and Threats). Analisis SWOT dilakukan untuk mengidentifikasi secara sistematik antara kekuatan dan kelemahan dari faktor internal serta peluang dan ancaman dari faktor eksternal yang dihadapi, sehingga dapat dibuat suatu alternatif strategi. Analisis SWOT digunakan untuk mengetahui situasi wisata melalui identifikasi faktor eksternal dan internal yang berpengaruh pada objek dan taman wisata alam Tahura Lapak Jaru, serta mengetahui peluang dan kekuatan yang dimiliki untuk menentukan rencana serta mengatasi kelemahan dan ancaman dengan rencana perbaikan.

Data diambil dengan cara observasi, wawancara, dan dokumentasi (foto dan peta). Data yang digunakan bersumber dari data primer dan data sekunder. Data primer diperoleh melalui observasi, wawancara, dan dokumentasi.

Responden penelitian merupakan informan kunci yang bersentuhan langsung dengan objek wisata Tahura Lapak Jaru. Penentuan strategi pengembangan ODWTA Tahura Lapak Jaru dilakukan dengan analisis SWOT. Data responden penelitian ditampilkan pada Tabel 1 dan daya tarik dan fasilitas di Tahura Lapak Jaru disajikan pada Gambar 1.

Tabel 1. Data responden penelitian

\begin{tabular}{clclc}
\hline No & \multicolumn{1}{c}{ Nama } & Umur & \multicolumn{1}{c}{ Instansi } & Jabatan \\
\hline 1 & Siren, SE., MM & 54 & Dinas Pariwisata dan Kebudayaan & Sekretaris Dinas \\
2 & Ruby Haris, ST & 36 & Dinas Pemberdayaan Masyarakat dan Desa & Kabid Pemberdayaan Masyarakat \\
3 & Ida Ayu S & 32 & Pelaku Usaha & Pemilik Usaha \\
4 & Susilo Benektus, ST & 57 & Dinas Pendidikan Pemuda dan Olahraga & Kabid Sekolah Menengah \\
5 & Kaharap, S.Hut & 39 & Dinas Kehutanan dan Pertanahan & Kasubag Perencanaan \\
6 & Deslan & 38 & Pemerintahan Desa & Sekretaris Desa \\
7 & Yoga Apriangga & 25 & PT. Erla Travel Tour & Direktur \\
8 & Telok, ST & 51 & Dinas Lingkungan Hidup & Kasi Pengawasan Lingkungan \\
9 & Yehuda & 40 & Lembaga Adat & Damang Kepala Adat \\
10 & Yohannes, SH & 42 & Bappeda & Kabid Sosial Ekonomi \\
11 & Heppy K, SH & 42 & Perusahaan Besar Swasta (PBS) & Kepala HRD PT. BMW
\end{tabular}



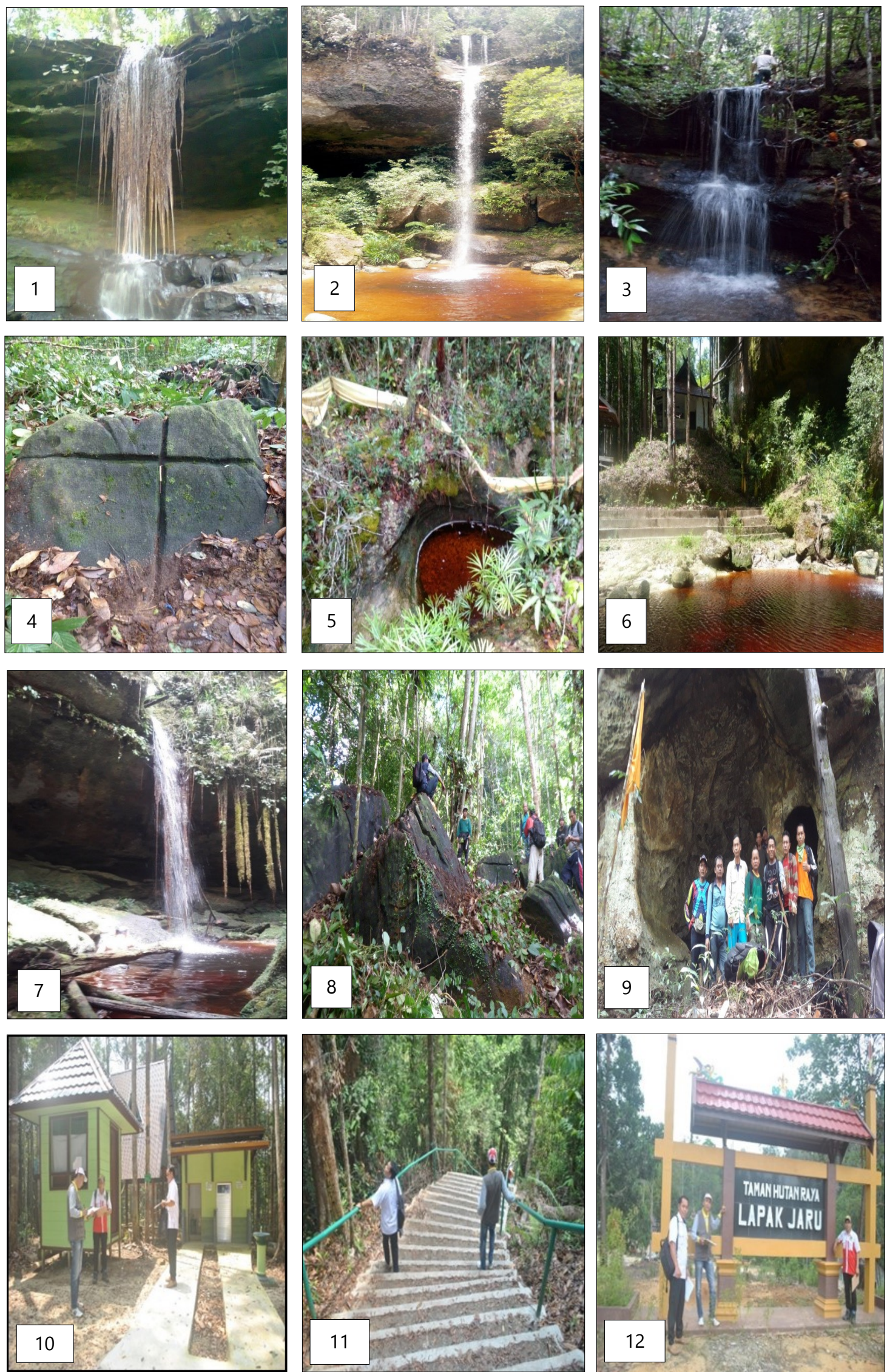

Gambar 1. Daya tarik dan fasilitas di Tahura Lapak Jaru. (1) Air terjun Danum Bahandang, (2) Air terjun Bawin Kameloh, (3) Air terjun Saluhan, (4) Air terjun Sahay Unyang, (5) Pemandian Bawin Kameloh, (6) Balai Bawin Kameloh, (7) Batu Salib, (8) Situs sejarah Batu, (9) Goa Lapak Jaru, (10) Sarana toilet dan ruang ganti, (11) Tangga menuju air terjun Bawin Kameloh, (12) Papan nama Tahura . 


\section{HASIL}

\subsection{Identifikasi Potensi Wisata di Tahura Lapak Jaru}

Kriteria penilaian objek wisata merupakan suatu instrumen untuk mendapatkan kepastian kelayakan suatu obyek untuk dikembangkan sebagai obyek wisata. Fungsi dari kriteria adalah sebagai dasar dalam pengembangan objek dan daya tarik wisata melalui penetapan unsur kriteria, penetapan bobot, perhitungan masing-masing sub unsur dan penjumlahan dari semua kriteria (Dirjen PHKA, 2003). Kriteria penilaian dilakukan terhadap daya tarik, potensi pasar, aksesibilitas, kondisi sekitar kawasan, pengelolaan dan pelayanan, iklim, akomodasi, prasarana dan sarana penunjang, ketersediaan air bersih, hubungan dengan objek wisata sekitarnya, keamanan, daya dukung kawasan, pengaturan pengunjung, pemasaran dan pangsa pasar.

\section{Daya Tarik}

Penilaian terhadap kawasan objek wisata tahura Lapak Jaru terhadap komponen daya tarik ditampilkan pada Gambar 2.

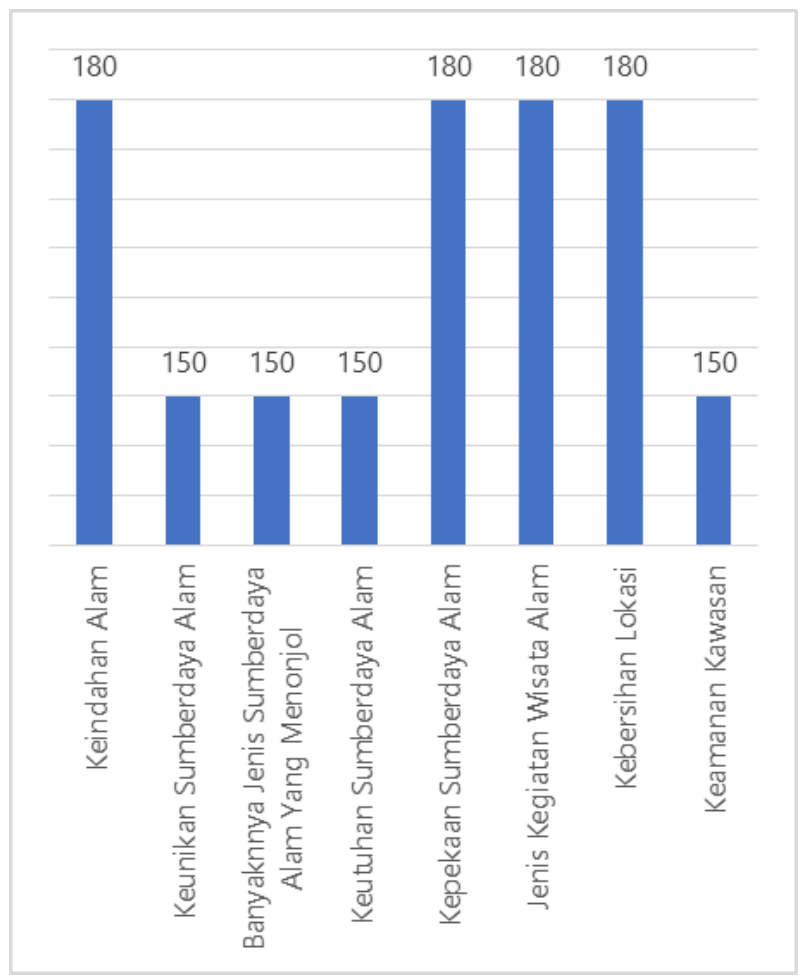

Gambar 2. Penilaian komponen daya tarik objek wisata Tahura Lapak Jaru

Hasil penelitian menunjukkan bahwa ada 5 kriteria yang memilki nilai tertinggi yaitu komponen keindahan alam, keutuhan sumberdaya alam, kepekaan sumberdaya alam, jenis kegiatan wisata alam, dan kebersihan lokasi. Sedangkan kriteria yang memperoleh nilai rendah yaitu keunikan sumberdaya alam, banyaknya jenis sumberdaya alam yang menonjol, keutuhan sumberdaya alam dan keamanan Kawasan.

\section{Potensi Pasar}

Kriteria unsur-unsur potensi pasar suatu objek wisata yaitu jumlah penduduk dan tingkat kebutuhan wisata. Penilaian terhadap komponen potensi pasar objek wisata Tahura Lapak Jaru ditampilkan pada Gambar 3. Berdasarkan hasil penelitian penilaian terhadap komponen potensi pasar menunjukkan jumlah penduduk/provinsi mendapat nilai yang tinggi dengan rentang kepadatan penduduk antara 101-200 km². Tingkat kebutuhan wisata pun memperoleh nilai yang tinggi yaitu 150 dengan beberapa kriteria yaitu tingkat pendapatan perkapita tinggi, tingkat kesejahteraan baik, tingkat kejenuhan penduduk tinggi, kesempatan ada dan perilaku berwisata.

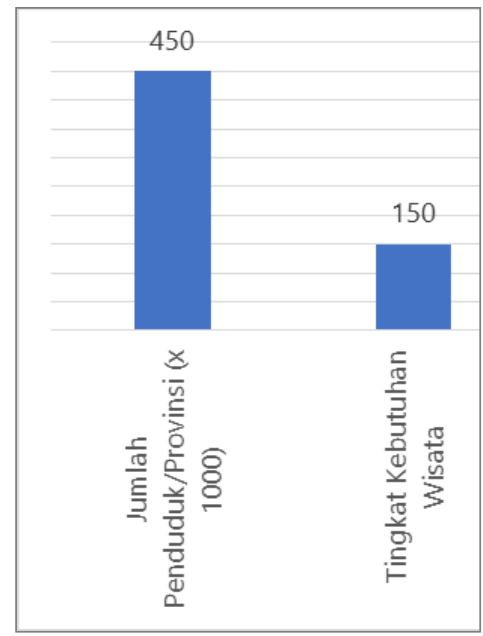

Gambar 3.

Penilaian

komponen potensi pasar objek wisata

Tahura Lapak Jaru

\section{Kadar Hubungan/Aksesibilitas}

Penilaian terhadap komponen kadar hubungan/ aksesibilitas di objek wisata taharu Lapak Jaru ditampilkan pada Gambar 4. Hasil penelitian menunjukkan bahwa kondisi dan jarak jalan darat dari ibukota Provinsi mendapatkan nilai tertinggi pada komponen penilaian aksesibilitas dengan jarak tempuh 151-150 km tetapi waktu tempuh dari ibukota provinsi memperoleh nilai terendah. Ha ini karena jarak tempuh yang dibutuhkan untuk mencapai Tahura lapak Jaru berkisar antara 4-5 jam sehingga wisatawan banyak menghabiskan waktu dalam perjalanan.

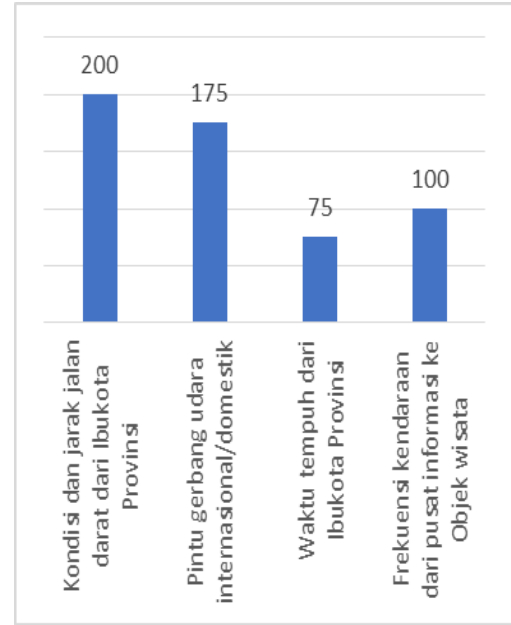

Gambar 4.

Penilaian komponen aksesibilitas objek wisata Tahura Lapak Jaru 


\section{Kondisi Sekitar Kawasan}

Penilaian terhadap komponen kondisi sekitar kawasan di objek wisata taharu Lapak Jaru ditampilkan pada Gambar 5 .

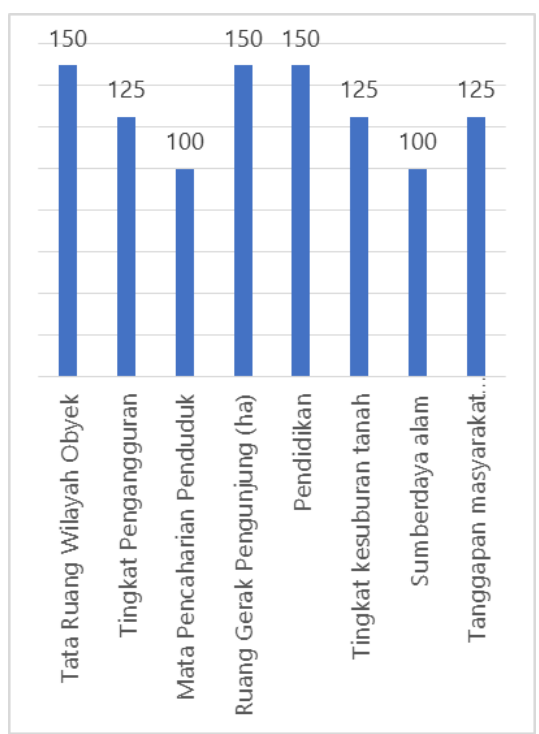

Gambar 5. Penilaian komponen kondisi sekitar kawasan objek wisata Tahura Lapak Jaru

\section{Pengelolaan dan Pelayanan}

Penilaian terhadap komponen pengelolaan dan pelayanan di objek wisata taharu Lapak Jaru ditampilkan pada Gambar 6. Hasil penelitian mengenai penilaian komponen pengengelolan dan pelayanan menunjukkan bahwa pada unsur pengelolaan dan pelayanan pengunjung memperoleh nilai tertinggi yaitu 120 sedangkan pada unsur kemampuan berbahasa memperoeh nilai terendah yaitu 100 karena Bahasa yang digunakan oleh masyarakat sekitar hanya mnggunakan Bahasa daerah dan Bahasa Indonesia sedangkan kemampuan berbahsa asing sangat rendah/minim.

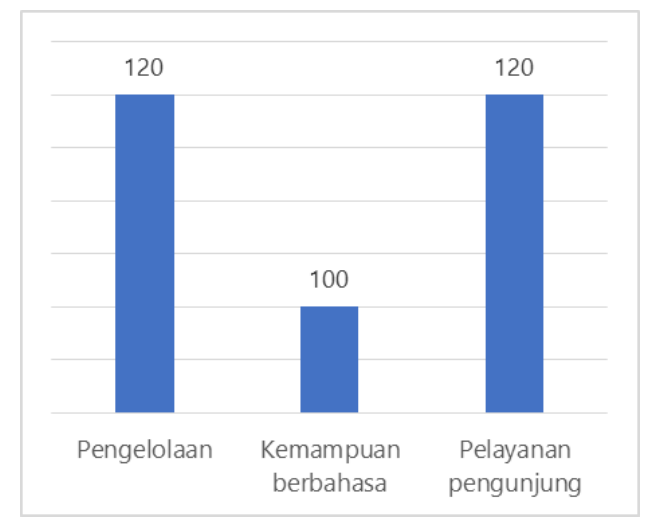

Gambar 6. Penilaian komponen pengelolaan dan pelayanan objek wisata Tahura Lapak Jaru

\section{Iklim}

Penilaian terhadap komponen iklim di objek wisata taharu Lapak Jaru ditampilkan pada Gambar 7. Hasil penilaian menunjukkan bahwa nilai tertinggi pada penilaian komponen iklim terdapat pada unsur kelembaban rata-rata pertahun yaitu 120 dan nilai terendah terdapat pada unsur suhu udara pada musim kemarau dan jumlah bulan kering rata-rata pertahun yaitu sebesar 80 .

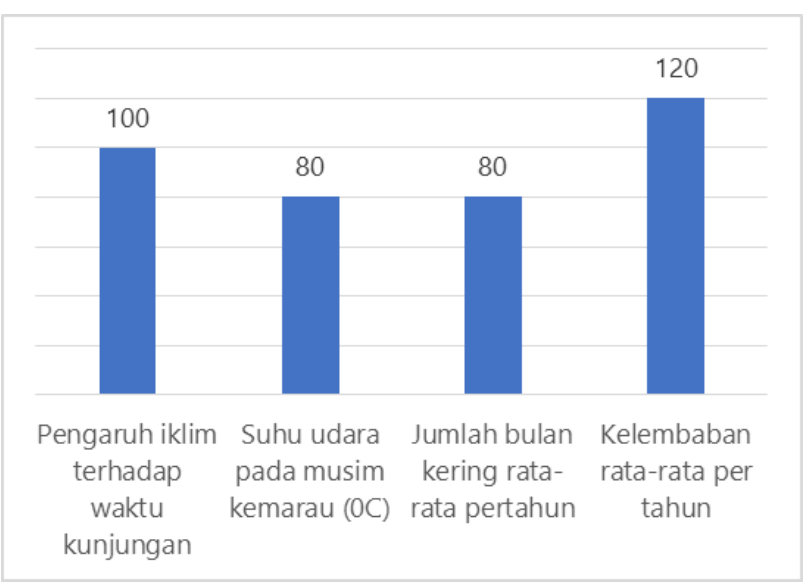

Gambar 7. Penilaian komponen iklim objek wisata Tahura Lapak Jaru

\section{Akomodasi}

Pengembangan suatu objek wisata tidak luput dari ketersediaan okomodasi yang memadai bagi para wisatawan yang hendak berkunjung ke objek wisata tertentu. Akomodasi dalam hal ini adalah segala Sesutu yang dibutuhkan oleh para wisatawan seama melakukan perjalanan wisata. Seperti hotel, restoran, rumah sakit, bank/ATM dan lainnya. Penilaian terhadap komponen akomodasi di objek wisata taharu Lapak Jaru memperoleh nilai 90. Akomodasi yang terdapat di Kuala Kurun ditampilkan pada Tabel 2.

Tabel 2. Akomodasi kota Kuala Kurun

\begin{tabular}{llc}
\hline No & \multicolumn{1}{c}{ Nama } & Jumlah \\
\hline & Hotel & 8 \\
2 & Home Stay & 5 \\
3 & Rumah Makan & 50 \\
4 & Bank & 6 \\
5 & Bandara & 1 \\
6 & Rumah Sakit & 1 \\
7 & Jaringan Komunikasi & 2 \\
\hline
\end{tabular}

\section{Sarana dan Prasarana Penunjang}

Penilaian terhadap komponen sarana dan prasarana di objek wisata taharu Lapak Jaru ditampilkan pada Gambar 8. Penilaian terhadap komponen sarana dan prasarana pada objek wisata nilai tertinggi yaitu pada unsur prasarana dengan nilai 90 yang terdiri dari jalan, jembatan, areal parkir, jaringan air minum dan jaringan telpon. Sedangkan pada unsur sarana memperoleh nilai yang rendah yaitu 60 . 


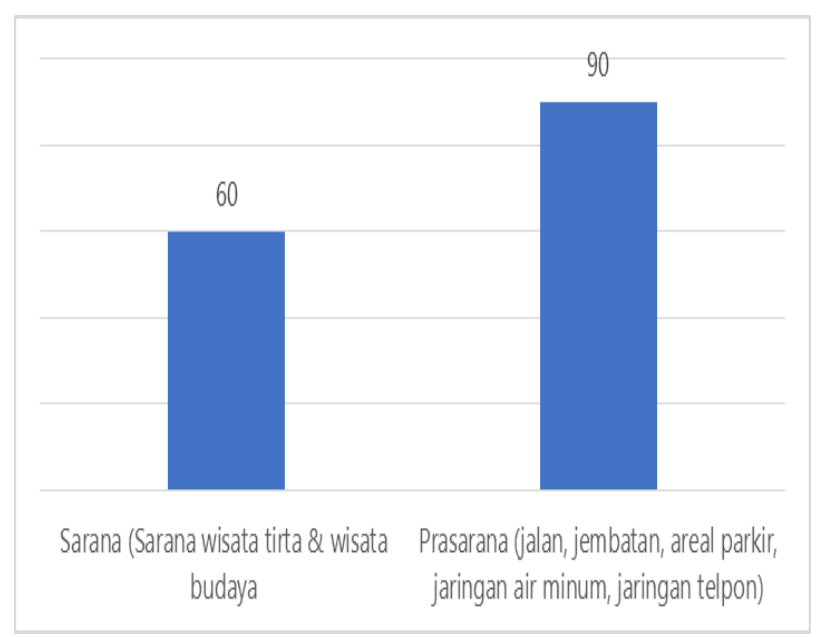

Gambar 8. Penilaian komponen sarana dan prasarana objek wisata Tahura Lapak Jaru

\section{Ketersediaan Air Bersih}

Penilaian terhadap komponen ketersediaan air bersih di objek wisata taharu Lapak Jaru ditampilkan pada Gambar 9. Hasil penelitian terhadap komponen ketersediaan air bersih diperoleh bahwa nilai tertinggi terdapat pada unsur volume, jarak lokasi air bersih terhadap objek dan ketersediaan air sepanjang tahun dengan nilai 180. Unsur dapat tidanya dialirkan ke objek dan kelayakan konsumsi memperoleh nilai 150.

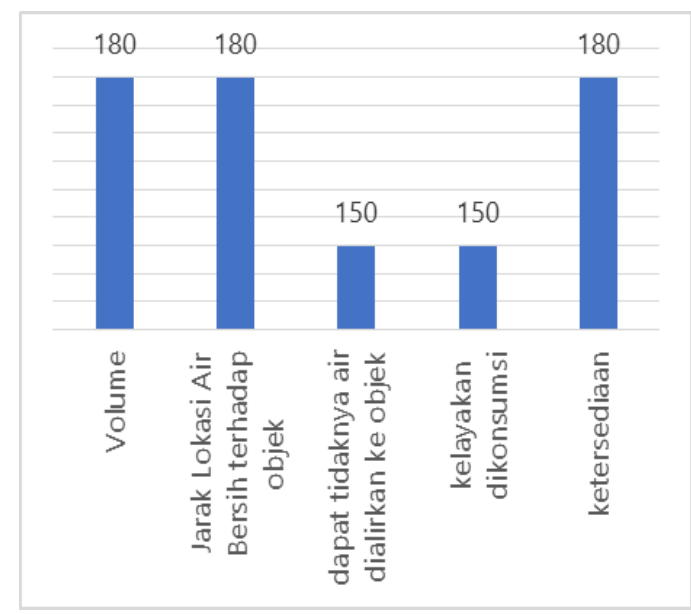

Gambar 9. Penilaian komponen ketersediaan air bersih objek wisata Tahura Lapak Jaru

10. Hubungan dengan Objek Wisata Sekitarnya

Salah satu hal yang perlu diperhatikan dalam pengembangan suatu ojek wisata adalah hubungan dengan objek wisata sekitar sehingga pengembanganya dapat lebih maksimal. Penilaian terhadap komponen hubungan dengan objek wisata sekitar di objek wisata taharu Lapak Jaru ditampilkan pada Gambar 10. Hasil penelitian menunjukkan bahwa nilai tertinggi pada komponen hubungan objek sekitar kawasan terdapat pada jarak 101-150 km dari objek wisata dengan jenis wisata yang tak sejenis. Nilai tertinggi untuk wisata sejenis terdapat pada jarak $0 \mathrm{~s} / \mathrm{d} 50 \mathrm{~km}$ dari objek wisata dengan nilai 80 .

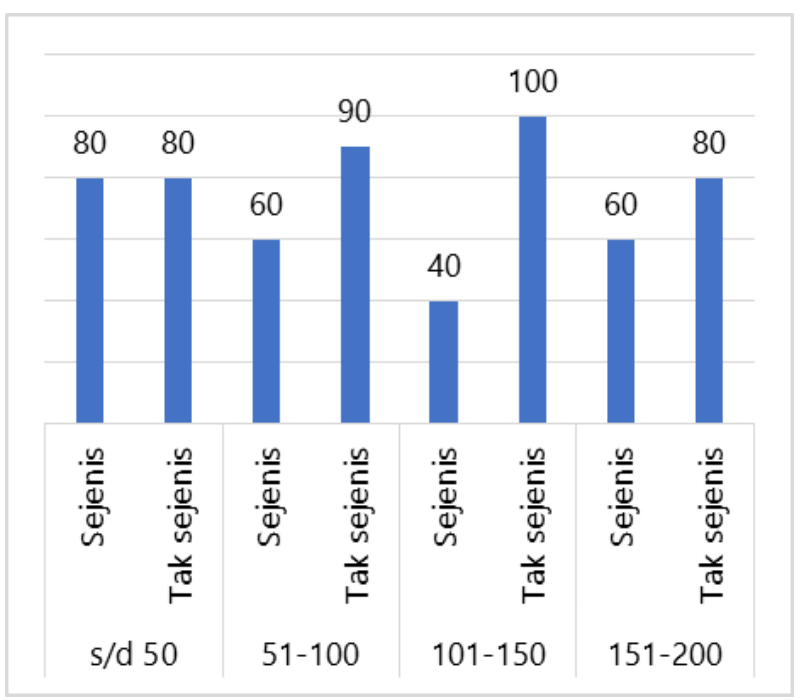

Gambar 10. Penilaian komponen hubungan objek wisata sekitar objek wisata Tahura Lapak Jaru

\section{Keamanan}

Penilaian terhadap komponen keamanan di objek wisata taharu Lapak Jaru ditampilkan pada Gambar 11. Hasil penelitian penilaian komponen keamanan pada objek wisata Tahura Lapak Jaru memperoleh nilai yang sama pada setiap unsur yaitu sebesar 125 . Unsur tersebut yaitu keamanan pengunjung, kebakaran, penebangan liar dan perambahan.

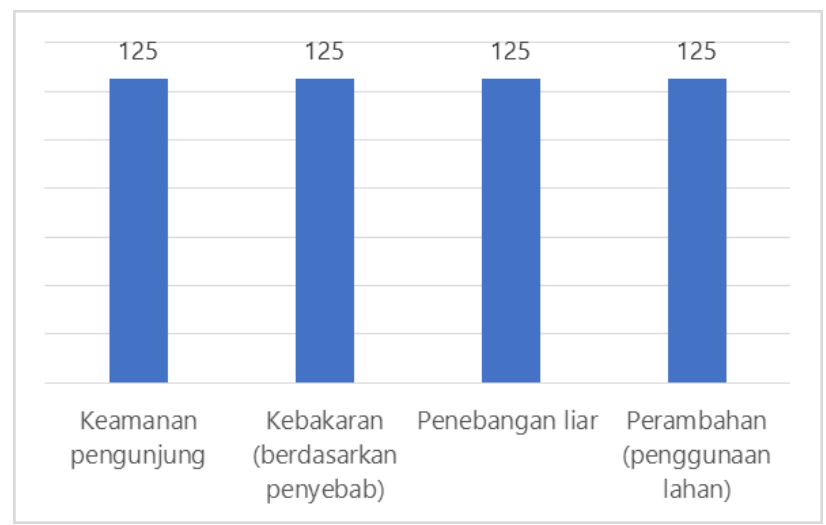

Gambar 11. Penilaian komponen keamanan objek wisata Tahura Lapak Jaru

\section{Daya Dukung Kawasan}

Penilaian terhadap komponen daya dukung kawasan di objek wisata taharu Lapak Jaru ditampilkan pada Gambar 12. Hasil peniaian terhadap komponen daya dukung kawasan nilai tertinggi pada unsur jumlah pengunjung, kemiringan lahan, dan luas unit zona yaitu sebesar 90. Unsur kepekaan tanah terhadap erosi dan jenis kegiatan memperoleh nilai 75 . 


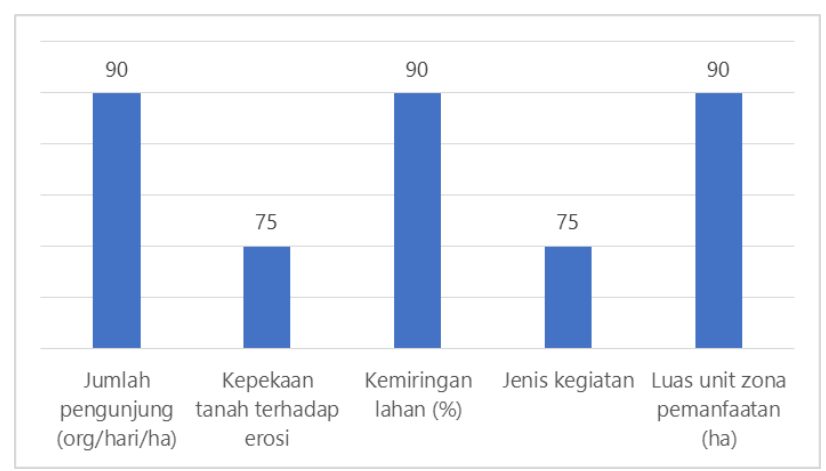

Gambar 12. Penilaian komponen daya dukung kawasan objek wisata Tahura Lapak Jaru

\section{Pengaturan Pengunjung}

Pengaturan pengunjung haruslah dilakukan dalam suatu objek wisata sehingga keamanan dan kenyamanan pengunjung tetap terjaga dan pengembangan terhadap objek wisata tersebut dapat lebih maksimal. Penilaian terhadap komponen pengaturan pengunjung di objek wisata taharu Lapak Jaru memperoleh nilai 45 dengan sub unsur distribusi pengunjung dan pemsatan kegiatan pengunjung.

\section{Pemasaran}

Aspek yang sangat penting dalam pengembangan suatu wisata adalah pemasaran. Promosi yang tepat sasaran akan meningkatkan jumlah pengunjung terhadap objek wisata tersebut. Tanpa adanya promosi sangat mustahil objek wisata tersebut dapat dikembangkan. Penilaian terhadap komponen pemasaran di objek wisata taharu Lapak Jaru dengan unsur tarif/harga terjangkau, produk wisata (ODTWA) bervariasi, sarana penyampaian informasi dan promosi memperoleh nilai 120.

\section{Pangsa Pasar}

Penilaian terhadap komponen pangsa pasar di objek wisata taharu Lapak Jaru ditampilkan pada Gambar 13. Penilaian terhadap komponen pangsa pasar pada unsur tingkat pendidikan dan mata pencaharian memperoeh nilai 75 dan pada unsur asal pengunjung memperoleh nilai 60 karena pengunjung Tahura Lapak Jaru masih terbatas dari dalam kabupaten tersebut.

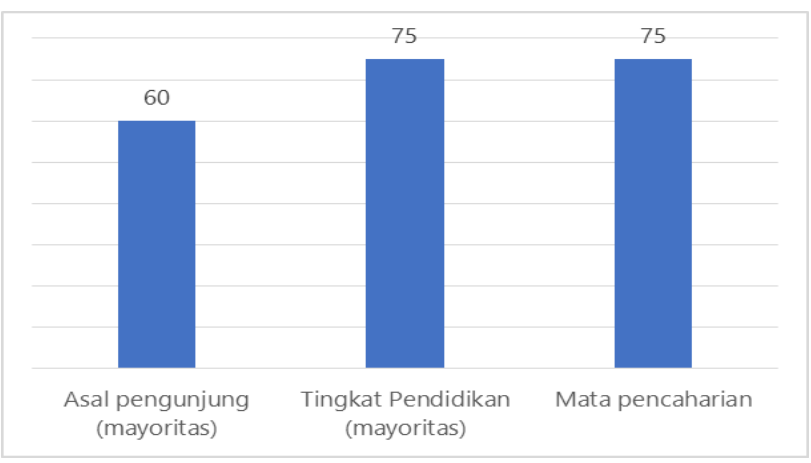

Gambar 13. Penilaian komponen pangsa pasar objek wisata Tahura Lapak Jaru.

\subsection{Rekapitulasi Penilaian ODTWA Blok Pemanfaatan Tahura Lapak Jaru}

Penilaian ODTWA dilakukan untuk mengetahui kelayakan pengembangan suatu objek wisata. Penilaian dilakukan dengan beberpa kriteria yaitu komponen daya tarik, potensi pasar, aksesibilitas, kondisi sekitar kawasan, pengelolaan dan pelayanan, iklim, akomodasi, prasarana dan sarana penunjang, ketersediaan air bersih, hubungan dengan objek wisata sekitarnya, keamanan, daya dukung kawasan, pengaturan pengunjung, pemasaran dan pangsa pasar. Hasil penilaian dapat digunakan sebagai acuan dalam pengembangan wisata. Hasil rekapitulasi penilaian kriteria ODTWA blok pemanfaatan Tahura Lapak Jaru ditampilkan pada Gambar 14.

Berdasarkan Gambar 14 ditampilkan bahwa komponen yang memperoleh nilai tertinggi pada kriteria penilaian adalah komponen daya Tarik dengan nilai 1350, kemudian dilanjutkan dengan komponen kondisi sekitar kawasan yaitu 1025, komponen ketersediaan air bersih memperoleh nilai 810 , selanjutnya komponen potensi pasar memperoleh nilai 600, disusul oleh komponen hubungan dengan objek wisata sekitar dengan nilai 590, komponen aksesibilitas memperoleh nilai 550, komponen keamanan objek memperoleh nilai 500, serta komponen lainnya masing-massing memperoleh nilai seperti yang tertera pada Gambar 14, sedangkan komponen yang memperoleh nilai terendah yaitu komponen pengaturan pengunjung yang memperoleh nilai 45 .

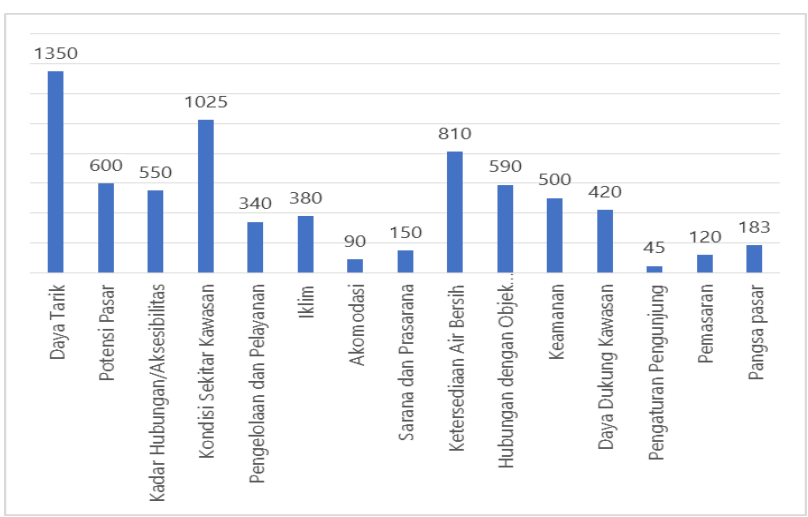

Gambar 14. Penilaian kelayakan pengembangan objek wisata Tahura Lapak Jaru

Berdasarkan hasil rekapitulasi penilaian kriteria pengembangan ODTWA blok pemanfaatan Tahura Lapak Jaru maka dapat ditentukan fokus pengembangan yaitu pada komponen potensi pasar, pengaturan pengunjung, dan pangsa pasar. Berdasarkan Hasil perhitungan analisis kelayakan menunjukkan bahwa jumlah skor total dari masing-masing kriteria yang diperoleh yaitu sebesar 7005 dengan ketegori A yaitu potensial untuk dikembangkan sebagai tujuan wisata.

\subsection{Strategi Pengembangan Tahura Lapak Jaru}

Strategi pengembangan Tahura Lapak Jaru ditampilkan pada tabel internal factor evaluation (IFE) dan tabel external factor evaluation (EFE) berikut. 
Tabel 3. Matrik internal factor evaluation (IFE)

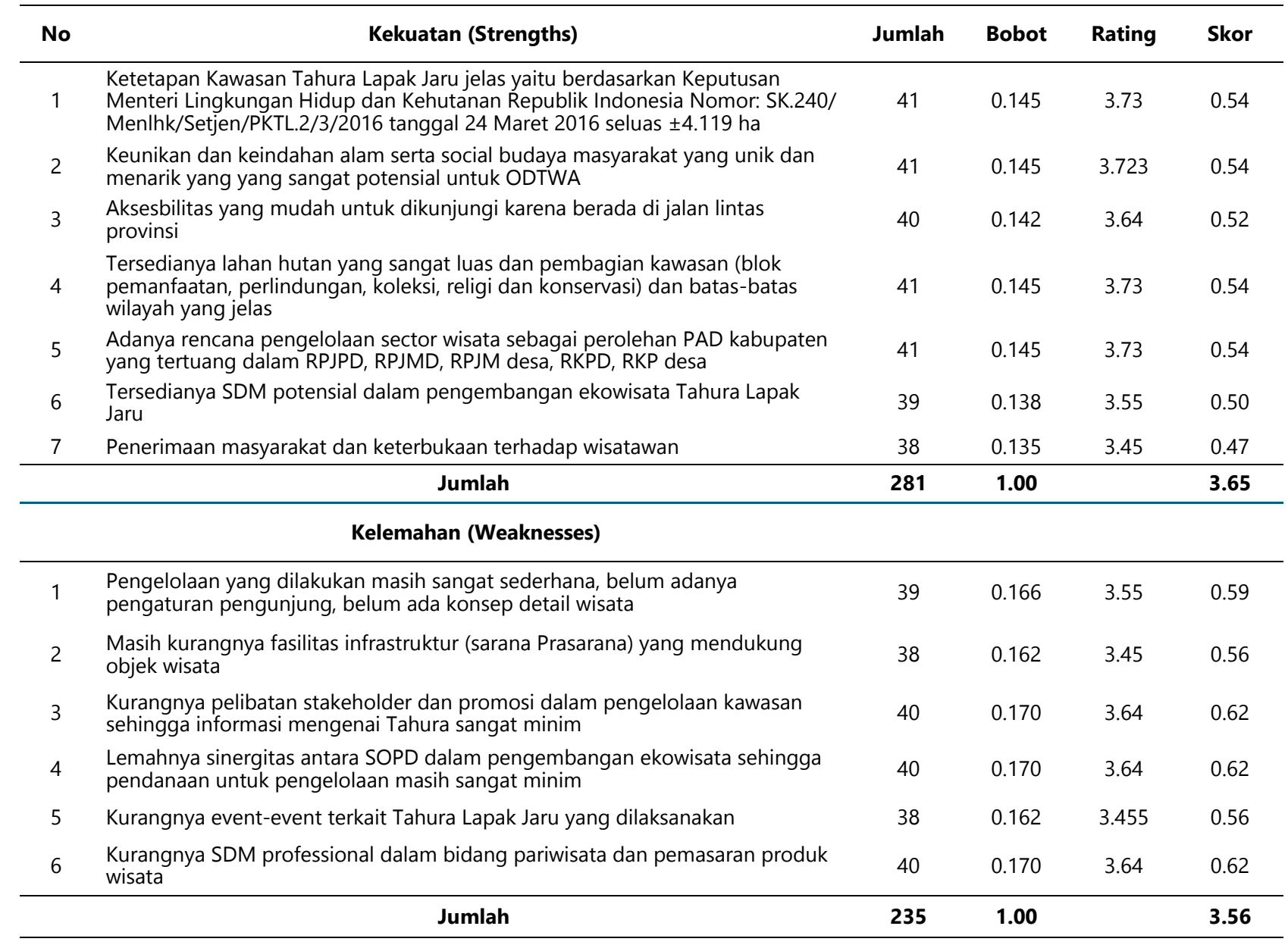

Tabel 4. Matriks eksternal factor evaluation (EFE)

\begin{tabular}{|c|c|c|c|c|c|}
\hline No & Peluang (Opportunities) & Jumlah & Bobot & Rating & Skor \\
\hline 1 & Trend wisata back to nature yang meningkat & 38 & 0.163 & 3.45 & 0.56 \\
\hline 2 & Potensi sumberdaya ekowisata Tahura dapat dikembangkan menjadi ODTWA & 40 & 0.172 & 3.62 & 0.62 \\
\hline 3 & Dukungan pemerintah daerah yang cukup tinggi untuk pengembang ODTWA & 40 & 0.172 & 3.62 & 0.62 \\
\hline 4 & $\begin{array}{l}\text { Keberadaan travel agent dan munculnya pusat-pusat perbelajaan/pusat } \\
\text { souvenir yang mendukung wisata }\end{array}$ & 37 & 0.159 & 3.36 & 0.53 \\
\hline 5 & Kerjasama dengan pihak pengembang sangat terbuka & 39 & 0.167 & 3.55 & 0.60 \\
\hline \multirow[t]{3}{*}{6} & $\begin{array}{l}\text { Peningkatan ekonomi masyarakat sekitar Kawasan dengan adanya Tahura Lapak } \\
\text { Jaru }\end{array}$ & 39 & 0.167 & 3.55 & 0.60 \\
\hline & Jumlah & 233 & 1.00 & & 3.53 \\
\hline & Ancaman (Threats) & & & & \\
\hline 1 & Persaingan dalam industry wisata yang sangat ketat & 37 & 0.179 & 3.36 & 0.60 \\
\hline 2 & $\begin{array}{l}\text { Ego sektoral antar lintas SOPD dan kurangnya koordinasi antar SKPD terkait } \\
\text { kelancaran dan keberlangsungan program kerja pengembangan dan } \\
\text { pembangunan kawasan Tahura }\end{array}$ & 39 & 0.188 & 3.55 & 0.67 \\
\hline 3 & $\begin{array}{l}\text { Perilaku pengunjung yang kurang memperhatikan etika lingkungan dan } \\
\text { perusakan terhadap fasilitas disekitar objek wisata }\end{array}$ & 39 & 0.188 & 3.55 & 0.67 \\
\hline 4 & Terjadinya bencana alam & 31 & 0.150 & 2.82 & 0.42 \\
\hline 5 & Terjadinya perubahan sosial budaya masyarakat sekitar kawasan & 29 & 0.140 & 2.64 & 0.37 \\
\hline \multirow[t]{2}{*}{6} & Keberadaan perusahan-perusahaan disekitar Tahura Lapak Jaru & 32 & 0.155 & 2.91 & 0.45 \\
\hline & Jumlah & 207 & 1.00 & & 3.18 \\
\hline
\end{tabular}




\subsection{Matriks Space}

Penentuan posisi strategi pengembangan objek wisata Tahura Lapak Jaru diperoleh berdasarkan analisis matriks space dan grand strategy selection matriks. Berdasarkan hasil perhitungan analisis matriks space (Tabel 5), bahwa posisi strategi pengembangan Tahura Lapak Jaru berada di kuadran I Garis vektor bersifat positif untuk faktor internal dan bersifat positif untuk faktor eksternal.

Tabel 5. Analisis matriks space pengembangan Tahura Lapak Jaru

\begin{tabular}{lcc}
\hline \multicolumn{1}{c}{ Analisis } & Nilai & Indeks \\
\hline Analisis Faktor Internal & & \\
A $\quad$ Kekuatan & & \\
B Kelemahan & 3.65 & $\mathbf{0 . 0 9}$ \\
Analisis Faktor Eksternal & 3.56 & \\
A Peluang & & \\
B Ancaman & 3.53 & $\mathbf{0 . 3 5}$ \\
\hline
\end{tabular}

\section{PEMBAHASAN}

\subsection{Identifikasi Potensi Wisata di Tahura Lapak Jaru} 1. Daya Tarik

Daya Tarik yang dimiliki oleh tahura Lapak Jaru berupa fisik dan biologi. Obyek dan daya tarik fisik meliputi fenomena alam dan bentang alam menarik yang ada di suatu kawasan. Tahura Lapak Jaru memiliki kekhasan fisik berupa air terjun dengan nuansa yang asri yang bagian dasarnya digunakan sebagai tempat pemandian bagi para pengunjung. Debit air terjun tersebut tidak tetap karena tergantung pada musim. Pada saat musim hujan debit air menjadi lebih besar dan pada musim kemarau debit air menjadi kecil. Selain itu, terdapat suatu fenomena menarik yang ditemui di tahura Lapak Jaru. yaitu fenomena alam berupa batuan yang berbentuk salib (batu salib) serta terdapat Goa yang juga memiliki keunikan dan kekhasan yang sangat menarik. Obyek dan daya tarik biologi meliputi berbagai jenis satwa dan vegetasi yang dapat dijadikan sebagai potensi wisata. Secara keseluruhan, terdapat 118 jenis satwa yang ditemukan di resor tahura Lapak Jaru. Jenis-jenis tersebut terdiri dari 14 jenis mamalia, 88 jenis burung, 8 jenis reptil, serta 7 jenis amfibi. Potensi-potensi tersebut ditemukan di kawasan blok pemanfaatan. Daya tarik wisata yang menunjang Objek Wisata Alam Tahura Lapak Jaru adalah adanya fasilitas wisata air berupa kolam renang, area bumi perkemahan, aula pertemuan, panggung hiburan, lapangan parkir yang cukup luas, area bermain anak, musholla, gazebo, rumah pohon toilet, dan tempat sampah. Keunikan dan keberagaman pesona pariwisata yang disampaikan oleh Direktorat Wisata Alam dan Pemanfaatan Jasa Lingkungan.

\section{Potensi Pasar}

Potensi pasar objek wisata tahura Lapak Jaru masih tergolong rendah. Hal ini disebabkan karena mayoritas pengunjung merupakan masyarakat yang berada disekitar kawasan objek wisata tahura Lapak Jaru yang mana tingkat pendapatan perkapita masih rendah, sehingga minat berwisata kurang. Untuk itu perlu memaksimalkan potensi pasar anak muda dengan trend selfi dengan pembangunan daya tarik yang ikonik, atau dalam bahasa populer dikenal dengan istilah instagramable. Selain itu melakukan upaya promosi melalui media elektronik dan internet, seperti pembuatan website, sosial media dan lain sebagainya. internet dipilih sebagai media paling efektif mengingat peluang pasar (pengguna internet/sosial media) sangat besar.

\section{Kadar Hubungan/Aksesibilitas}

Tahura Lapak Jaru memiliki aksesibilitas yang baik dari ibukota Kabupaten Gunung Mas $( \pm 6 \mathrm{Km}$ dari Kota Kuala Kurun), dengan waktu tempuh tidak lebih dari 15 menit dari kota Kuala Kurun, wisatawan tidak memerlukan banyak waktu untuk menikmati obyek wisata yang terdapat di Tahura Lapak Jaru. Hanya saja untuk mencapai tempat wisata dari ibukota provinsi memerlukan waktu yang cukup lama yaitu berkisar antara 4-5 jam perjalanan meskipun melewati jalan beraspal. Untuk mencapai lokasi objek wisata dapat menggunakan kendaraan roda empat dan roda dua. Jalan menuju lokasi objek wisata beraspal sampai pintu masuk lokasi wisata. Selanjutnya untuk mencapai objek-objek daya tarik wisata harus ditempuh menggunakan motor atau berjalan kaki mengingat kondisi menuju objek daya tarik turun naik.

\section{Kondisi Sekitar Kawasan}

Kondisi sekitar kawasan objek wisata tahura Lapak Jaru dalam kategori yang baik. Hal ini didukung oleh tata ruang wilayah objek wisata yang sangat sesuai sehingga ruang gerak pengunjung tidak terganggu, sumberdaya alam sekitar kawasan potensial untuk dikembangkan tingkat pengangguran yang tidak terlalu tinggi serta masyarakat mendukung pengembangan kawasan objek wisata tahura.

\section{Pengelolaan dan Pelayanan}

Pengelolaan objek wisata tahura Lapak Jaru yang dilakukan oleh pemerintah sangat baik, pemerintah telah melaksanakan tugasnya sebagai sebagai pengelola utama objek wisata tahura Lapak Jaru. Aspek pelayanan masih kurang dalam kemampuan berbahasa karena hanya menggunakan bahasa daerah setempat dan bahasa Indonesia ketika berkomunikasi. Sedangkan kemampuan dalam berbahasa asing masih rendah, untuk itu perlu kiranya diberikan pelatihan atau kursus berbahasa asing mengingat besarnya potensi kunjungan wisatawan mancanegara.

\section{Iklim}

Tahura Lapak Jaru memiliki tipe iklim A yang mana suhu udara pada musim kemarau berkisar antara $22-24^{\circ} \mathrm{C}$, 
jumlah bulan kering rata-rata pertahun selama 7 bulan dan kelembaban rata-rata pertahun $>65 \%$. Kunjungan wisatawan ke tahura Lapak Jaru selama ini tidak bergantung kepada iklim. Jumlah pengunjung relative konstan bahkan meningkat.

\section{Akomodasi}

Akomodasi yang terdapat di kota Kuala Kurun yang merupakan kota lokasi objek wisata tahura Lapak Jaru sangat memadai karena di Kuala Kurun terdapat beberapa hotel, homestay, losmen, restoran, bank. Sarana akomodasi hotel merupakan bagian yang strategis untuk mempromosikan objek dan daya tarik wisata daerah, sebab hotel merupakan stakeholder pariwisata yang bekerja menjual jasa.

\section{Sarana dan Prasarana Penunjang}

Sebaik dan semenarik suatu atraksi yang ditampilkan oleh daerah wisata, belum akan memuaskan wisatawan yang berkunjung ke daerah wisata karena masih ada faktor lain yang menjadi pertimbangan menyangkut fasilitas-fasilitas penunjang yang memungkinkan mereka dapat menikmati kenyamanan, keamanan, dan lainnya. Terpenuhinya syarat tersebut tidak terlepas dari ketersediaan sarana dan prasarana seperti jalan raya, pusat perbelanjaan, bank, kantor pos, dan lainnya. Sarana prasarana penunjang di kawasan objek wisata tahura Lapak Jaru belum memadai untuk menunjang pengembangan wisata sehingga perlu disediakan shelter, mini map dan lainnya yang menunjang pengembangan Kawasan.

\section{Ketersediaan Air Bersih}

Ketersediaan air bersih di kota Kuala Kurun telah memadai karena telah tersedia sumur-sumur dan PDAM. Air diperuntukkan bagi para wisatawan baik untuk minum atau pun keperluan lainnya.

\section{Hubungan dengan Objek Wisata Sekitar}

Objek wisata tahura Lapak Jaru memiliki hubungan dengan objek wisata sekitarnya. Salah satu objek wisata yang terdekat dengan tahura yang sejenis yaitu objek wisata air terjun Batu Mahasur dan objek wisata yang tidak sejenis yaitu objek wisata buatan berupa DAM Sekata Juri. Selain itu juga terdapat wisata sejarah yaitu Situs Rangan Sambon dan Ulek Tumbang Purang Kuluk Kasintu. Dengan adanya hubungan tersebut akan mempermudah pengembangan objek wisata yang berada di Kabupaten Gunung Mas sehingga dapat dilakukan wisata one day untuk beberapa lokasi wisata.

\section{Keamanan}

Tingkat keamanan pengunjung pada objek wisata tahura Lapak Jaru sangat baik karena objek wisata tahura Lapak Jaru memiliki tanah yang stabil dan tidak ada situs yang berbahaya, tidak terdapat gangguan dari kamtibnas, bebas dari kepercayaan yang menggangu, tidak ada penebangan liar, kebakaran hutan dan perambahan yang dilakukan disekitar tahura. Hanya saja kenyamanan pengunjung agak terganggu karena kurangnya pemahaman pengunjung yang rendah tentang sadar wisata.

\section{Daya Dukung Kawasan}

Tahura Lapak Jaru memiliki daya dukung kawasan yang sangat tinggi untuk dikembangkan sebagai objek wisata. Daya dukung Kawasan yang dimiliki oleh tahura Lapak jaru jenis kegiatan wisata yang dapat dilakukan berupa wisata alam, penelitian, berkemah dan mendaki hal ini didukung oleh luasnya zona pemanfaatan yang barengi dengan kemiringan lahan antara $0-8 \%$ dan tidak peka terhadap erosi sehingga keamanan pengunjung terjaga.

\section{Pengaturan Pengunjung}

Pengelolaan pengunjung tahura Lapak Jaru dimaksudkan untuk mengendalikan dampak negatif terhadap kualitas sumberdaya yang ada dan mengoptimalkan interpretasi pengunjung terhadap tahura Lapak Jaru. Dengan demikian, pengelolaan pengunjung meliputi kegiatan pengaturan, pengamanan dan keselamatan pengunjung serta penerapan program interpretasi (musim kunjungan). Pengaturan pengunjung dilakukan dengan cara membuat peraturan dan tata tertib memasuki kawasan dan aktivitas di dalam kawasan serta dengan menyediakan pemandu dan program interpretasi.

\section{Pemasaran}

Pemasaran objek wisata tahura Lapak Jaru sangat baik. Hal ini didukung oleh produk wisata yang dijual sangat bervariasi dengan daya tarik wisata alam yang sangat menarik. Selain itu, untuk dapat menikmati pesona alam yang sangat asri pengunjung pada saat ini tidak perlu mengeluarkan biaya yang banyak karena untuk masuk belum dikenakan biaya. Begitu juga dengan sarana penyampai informasi terkait wisata tahura lapak Jaru yang telah memadai. Promosi terkait keberadaan tahura masih minim sehingga perlu dilakukan peningkatan promosi melalui berbagai media cetak, elektronik, internet dan media social guna menambah kunjungan wisatawan.

\section{Pangsa Pasar}

Pangsa pasar objek wisata tahura Lapak Jaru masih tergolong rendah karena hanya mencakup wisatawan lokal. Selain itu mayoritas pengunjung adalah mereka yang memiliki tingkat Pendidikan menengah dan yang berprofesi sebagai pegawai negeri (PNS). Untuk itu diperlukan peningkatan promosi untuk menarik wisatawan dari luar daerah maupun wisatawan mancanegara.

\subsection{Strategi Pengembangan Tahura Lapak Jaru}

Tahap formulasi strategi merupakan langkah untuk menentukan alternatif-alternatif strategi yang dapat 
diambil dalam upaya pengembangan tahura Lapak Jaru dan dituangkan dalam matriks SWOT. Perumusan strategi menghasilkan empat alternatif, yaitu:

\section{Strategi SO (Strengths-Opportunities)}

Strategi SO adalah strategi yang menggunakan kekuatan yang dimiliki untuk memanfaatkan peluang yang ada. Berdasarkan hasil analisis pada matriks SWOT dari kekuatan dan peluang yang diperoleh, maka strategi yang sebaiknya dilakukan oleh tahura Lapak Jaru yaitu:

a. Mempertahankan posisi sebagai tempat wisata yang memiliki SDA yang sangat potensial untuk objek wisata yang didukung oleh status Kawasan sebagai tahura, aksesibilitas yang mudah dan tingginya dukungan pemerintah serta peluang kerjasama yang tinggi dengan pengembang dan SDM yang potensial serta adanya perkembangan teknologi informasi yang pesat yang dapat mendukung ODTWA yang sangat kuat.

b. Merencanakan pengembangan Kawasan yang harus lebih mengikutsertakan partisifasi masyarakat setempat dalam pengelolaan ODTWA yang telah memiliki target konsumen, segmentasi dan focus pasar agar meraih peluang dalam trend wisata back to nature dan dukungan Pemda yang cukup tinggi terhadap ODTWA dalam rangka membangun pariwisata.

\section{Strategi WO (Weaknesses-Opportunities)}

Strategi WO adalah strategi yang mengatasi kelemahan yang dimiliki dengan memanfaatkan peluang yang ada dengan menerapkan hal berikut:

a. Mengoptimalkan perkembangan teknologi informasi dalam kegiatan promosi yang efektif dan efisien, brand image ODTWA yang telah terbentuk dan memanfaatkan dukungan dari pemerintah daerah serta melakukan kerjasama dengan pihak sponsor maupun investor agar meningkatkan aktivitas wisata yang lebih optimal.

b. Memanfaatkan perkembangan trend wisata back to nature dengan meningkatkan jumlah SDM yang professional dalam merancang strategi promosi yang lebih gencar, mempertimbangkan kembali strategi penetapan harga dan lebih memberikan perhatian terhadap aksesibilitas menuju ODTWA agar mendukung pengembangan ODTWA tahura Lapak Jaru sebagai jasa wisata yang diandalakan.

\section{Strategi ST (Strengths-Threats)}

Strategi ST merupakan strategi menghindari ancaman yang datang dari luar dengan menggunakan kekuatan yang dimiliki dengan menerapkan hal-hal berikut:

a. Mengembangkan potensi SDA ODTWA yang memiliki status kawasan tahura dan aksesibilitas yang mudah agar mendukung kesejahteraan masyarakat sekitar dengan cara memberikan peluang usaha untuk berjulan dan membuat souvenir khas OWA Tahura Lapak Jaru. b. Memprioritaskan dalam rencana pengembangan dengan mensinergitaskan kerjasama dengan semua stakeholder dalam mewujudkan sapta pesona pariwisata serta mengemas wisata dengan melakukan program wisata yang dapat bersaing dengan ODTWA lainnya dalam industry pariwisata tanpa melupakan pentingnya alam dan pengelolaan objek wisata berbasis konservasi.

\section{Strategi WT (Weaknesses-Threats)}

Strategi defensif yang diarahkan untuk mengurangi kelemahan internal serta menghindari ancaman eksternal. Langkah yang dapat diambil adalah sebagai berikut:

a. menambah poin ketertarikan investor dengan tetap mempertahankan kesejahteraan masyarakat sekitar dan menindak tegas perilaku-perilaku pengunjung yang kurang baik (vandalism, buang sampah sembarangan) dengan melakukan pengawasan yang intensif.

b. Menjalankan capacity building SDM secara rutin dalam bidang pemasaran dan pariwisata untuk meningkatkan kualitas produk dan pelayanan kepada pengunjung dan msyarakat sekitar untuk menghadapi pesaing dalam industry pariwisata.

Kekhasan Tahura Lapak Jaru menjadi satu potensi sebagai kekuatan dan peluang yang dimiliki untuk dilakukan pengembangan usaha, sehingga dalam pengelolaan dan pengembangan objek wisata tersebut harus dilakukan dengan baik dan ditangani secara serius. Salah satu objek yang terdapat di Kabupaten Gunung Mas tersebut, Tahura Lapak Jaru juga memerlukan upaya peningkatan kerjasama dengan pihak terkait. Strategi hasil penelitian ini sejalan dengan hasil penelitian Xavier et al. (2018) dan Hidayat (2016).

Peningkatan koordinasi dan kerjasama denga instansi terkait serta keterlibatan masyarakat perlu dilakukan sebagai salah satu strategi dalam pengembangan Taman Hutan Raya Wan Abdul Rachman Lampung (Xavier et al., 2018). Pariwisata memerlukan pengelolaan yang serius dengan melibatkan intansi terkait dan masyarakat sekitar. Dukungan pemerintah baik pemerintah daerah maupun pemerintah pusat serta berbagai pihak terkait antara lain dalam hal penyediaan dana sebagai stimulan, pemeliharaan dan perbaikan jalan raya untuk meningkatkan akses menuju lokasi wisata, dukungan keamanan lingkungan, peningkatan pelayanan pengunjung, promosi paket wisata dan membangun jejaring bisnis (Hidayat, 2016).

\section{PENUTUP}

Hasil penelitian menunjukkan bahwa Tahura Lapak Jaru sangat potensial untuk dikembangkan untuk dijadikan objek wisata dengan perolehan penilaian kriteria pengembangan objek dan taman wisata alam (ODTWA) sebesar 7005 dengan kategori potensial untuk 
dikembangkan (A). Strategi pengembangan objek wisata tahura Lapak Jaru perlu menerapkan strategi agresif yaitu yang menggunakan kekuatan yang dimiliki untuk memanfaatkan peluang yang ada. Strategi pengembangan yang dapat dilakuukan adalah mempertahankan posisi sebagai temapat wisata yang memiliki SDA yang sangat potensial untuk objek wisata yang didukung oleh status kawasan sebagai tahura, aksesibilitas yang mudah dan tingginya dukungan pemerintah serta peluang kerjasama yang tinggi dengan pengembang dan SDM yang potensial serta adanya perkembangan teknologi informasi yang pesat yang dapat mendukung ODTWA yang sangat kuat serta merencanakan pengembangan kawasan yang harus lebih mengikutsertakan partisipasi masyarakat setempat dalam pengelolaan ODTWA yang telah memiliki target konsumen, segmentasi dan focus pasar agar meraih peluang dalam trend wisata back to nature dan dukungan Pemda yang cukup tinggi terhadap ODTWA dalam rangka membangun pariwisata.

\section{DAFTAR PUSTAKA}

Afriza, L., Kartika, T., \& Riyanti, A. (2018). Pengembangan Ekowisata Berbasis Masyarakat (Community Based Ecotourism) dalam Rangka Mengentaskan Kemiskinan Di Desa Karangsong Kabupaten Indramayu. Jurnal Sains Terapan Pariwisata, 3(1), 2034.

Direktorat Jenderal Perlindungan Hutan dan Konservasi Alam. (2003). Pedoman Analisis Daerah Operasi Obyek Dan Daya Tarik Wisata Alam. Bogor:
Direktorat Wisata Alam dan Pemanfaatan Jasa Lingkungan.

Hidayat, S. (2016). Strategi Pengembangan Ekowisata di Desa Kinarum Kabupaten Tabalong. Jurnal Hutan Tropis, 4(3), 282-292.

Latupapua, Y. T., Pudyatmoko, S., Fandeli, C., dan Baiquni, M. (2013). Analisis Potensi Keanekaragaman Hayati di Taman Nasional Manusela Sebagai Daya Tarik Ekowisata. Jurnal Agroforestri, 8(4), 248-260.

Mulyanie, E. (2016). Partisipasi masyarakat dalam pelestarian kawasan konservasi hutan di gunung galunggung kabupaten tasikmalaya. Jurnal Geografi, 4(1), 1-14.

Sahureka, M., Lelloltery, H., \& Hitipeuw, J. C. (2016). Implementasi pengembangan ekowisata berbasis masyarakat di hutan lindung gunung sirimau Kota Ambon. Jurnal Hutan Pulau-pulau Kecil, 1(2), 128135.

Sulisyati, R., Poedjirahajoe, E., Faida, L. R. W., \& Fandeli, C. (2016). Optimalisasi Zona Pemanfaatan Wisata Taman Nasional Karimunjawa Melalui Komunitas Ikan Karang (Optimizing The Tourism Utilization Zone Karimunjawa National Park through Coral Reef Fish Communities). Jurnal Manusia dan Lingkungan, 23(2), 224-232.

Wulan, C., Albayudi, A., \& Lidiarti, T. (2019). Analysis of Potential Ecotourism in the Rawa Bento, Kerinci District. Jurnal Silva Tropika, 3(1), 95-107.

Xavier, S., Harianto, S. P., \& Dewi, B. S. (2018). Pengembangan Penangkaran Rusa Timor (Cervus timorensis) di Taman Hutan Raya Wan Abdul Rachman Lampung. Jurnal Sylva Lestari, 6(2), 92104. 